\title{
A KLINIKAI PSZICHOLÓGIA 30 ÉVE
}

\section{PÉLEY BERNADETTE}

Pécsi Tudományegyetem, Pécs, Magyarország

E-mail: peley.bernadette@pte.hu

Beérkezett: 2021. november 14. - Elfogadva: 2021. december 13.

A klinikai pszichológia megalapozása a gyakorlati alkalmazás oldaláról kezdődött, a diagnosztikai módszerek rendszerezésével és adaptálásával. Az elmúlt harminc évben széles területet lefedô kutatások születtek, és maga a klinikai pszichológia is differenciálódott. A fejlódési pszichopatológia új perspektívát jelent a klinikai pszichológiai gondolkodásban, ami jól követhetô a különbözố pszichopatológiai jelenségek kutatásaiban is.

Kulcsszavak: diagnosztikai módszerek, gyakorlat és kutatás, fejlödési pszichopatológia

A klinikai pszichológia hosszú ideig elsôsorban múhelyként múködött. Az alapok lerakása, a klinikai pszichológiai munka szervezett megkezdése, a feltételek megteremtése Mérei Ferenc érdeme (Szakács, 2010; Ajkay és mtsai, 2020). Az azóta bezárt „Lipóton” létrejött Klinikai Pszichológiai Laboratórium az elsố klinikai gyakorlóhelye lett a pszichológusképzésnek. A további múhelyek kialakulásában és a szakmai folytonosságban fontos szerepe volt a pszichoanalitikus csoportoknak. A sok név közül kiemelkedố szerepe volt Nemes Líviának, Gerô Zsuzsának, akiknek az írásai elméleti és módszertani szempontból is meghatározóak voltak (Nemes, 2000; Geró, 2017).

A klinikai pszichológiával foglalkozó publikációk összességében is elsôsorban módszertani kérdésekkel és esetismertetésekkel foglalkoztak, valamint igen színvonalas szemletanulmányok, szerkesztett kötetek jelentek meg a legkorszerúbb nemzetközi irányok és elméletek bemutatásával. Ebben Buda Bélának elévülhetetlen érdemei vannak. 
Ahogy azt az esettanulmány-írás hagyományai is tükrözik, a pszichoterápia egyre nagyobb szerepet kapott a klinikai pszichológiai munkában, így jelentôs lépés volt a Pszichoterápia folyóirat megjelenése 1992-ben, amely a mai napig meghatározó szakmai folyóirat, és eredeti közlemények, kutatások is megjelennek benne.

Fontos lépés volt a diagnosztikai munkához szükséges tesztek magyar mintán történố adaptációja, ebben Szegedi Márton, Bagdy Emôke, Szakács Ferenc, valamint természetesen Mérei Ferenc úttörôk voltak. Sorra jelentek meg a klinikusok munkáját segítô módszertani kézikönyvek (Mérei és Szakács, 1988a, 1998b; Mérei és Szakács, 1994).

A klinikai munkában meghatározó módon használt projektív eljárások mellett egyre több kérdôíves eljárás került hazai alkalmazásra, ami nemcsak a diagnosztikai munkában, hanem az empirikus munkában is elôrelépést jelentett. Az esettanulmányok mellett megjelentek empirikus kutatások is, az MMPI gyakorlati alkalmazása (Bagdy, Pressing, Bugán és Zétényi, 1986), a Cloninger-féle temperamentum és karakter kérdôív (Rózsa, Kállai, Osváth és Bánki, 2005), kérdôívek és becslôskálák a klinikai pszichológiában (Perczel-Forintos, Ajtay, Barna, Kiss és Komlósi, 2018; Horváth, Urbán, Kökönyei és Demetrovics, 2021). A Magyar Pszichológiai Szemleben sorra jelennek meg olyan tanulmányok, melyekben egy-egy új kérdőives eljárás kerül bemutatásra. A módszertani választék emiatt ezen a területen rendkívül nagy lett. A Magyar Pszichológiai Társaság keretében múködô Tesztbizottság hosszú évek munkájával létrehozott egy tesztkatasztert, amely több mint hétszáz Magyarországon használt pszichológiai vizsgálóeszközrôl/tesztrôl szóló publikációt tart nyilván. A Bizottság megjegyzi, hogy a kiválasztásra, diagnosztizálásra és kutatásra használt tesztek jogi státusza és szakmai minôsége részben történelmi okokból meglehetôsen vegyes képet mutat (Nagy és Nagybányai, 2020). Erre való tekintettel a kataszter mellett közlésre kerültek mindenki számára elérhetố módon a tesztfejlesztés és adaptáció irányelvei és a tesztminôsítés folyamata.

A hazai klinikai pszichológia módszertanában a Rorschach-teszt kiemelt helyet foglal el, az eredeti Mérei-könyv Gerố Zsuzsa kiegészítéseivel, gondozásában újra megjelent (Mérei, 2002). Csigó Kata a Rorschach-teszt klinikai alkalmazásáról írt könyvet (Csigó, 2018), és tavaly az MPSZ-ben egy különszám jelent meg errôl a tesztrôl, illetve az ehhez kapcsolódó klinikai munkáról (Császár-Nagy, 2020). A teszt jelölésének és értékelésének új módszertana is megjelent itthon, a Rorschach Teljesítményértékelố Rendszer (R-PAS) és módszertani képzések is indultak (Nagy és Császár-Nagy, 2020). Ez az új irány és módszer lehetôséget kínál ezen a téren is az empirikus klinikai munka nemzetközi megjelenéséhez.

A 2000-es évek elejétốl egyre nagyobb differenciálódás indult el a klinikai területeken, és ezek már elnevezésükben is különböznek, önálló tudományterületet képviselnek (addiktológia, egészségpszichológia, valamint a mentálhigiéné is, amely korábban a klinikai pszichológiával összefonódva jelent meg). A képzôhelyeken önálló helyet foglalnak el a klinikai tárgyak, ezekhez kutatások társulnak. A szakma újrafogalmazása és útkeresése is ebben az idôben kezdôdik el (Kállai és Kézdi, 2003).

Egyre nagyobb hangsúly kerül a klinikai gyakorlati munka és a kutatások összekapcsolására. Egyes ellátó intézményekben nemzetközileg is releváns kutatások folynak. A teljesség igénye nélkül például Kéri Szabolcs, Csigó Katalin és Harsányi András kutatócsoportja a pszichiátriai zavarok neuropszichológiai vizsgálataival értek el 
nemzetközileg is érdekes eredményeket (pl. Csigó és mtsai, 2010; Fekete és mtsai, 2020; Harsányi és mtsai, 2014, 2015; Kéri, Kállai és Csigó, 2020; Maróthi, Csigó és Kéri, 2019) vagy éppen Perczel-Forintos Dóra és munkacsoportja a mentális zavarok hátterében álló kognitív-viselkedéses tényezôkre fókuszált (Kocsis-Bogár, Mészáros és Perczel-Forintos, 2018; Miklosi, Szabo, Martos, Galambosi és Perczel Forintos, 2013; Perczel-Forintos, Rózsa, Pilling és Kopp, 2013; Szabó és mtsai, 2016). A Pécsett múködô evolúciós pszichológiai kutatócsoportban is zajlanak pszichopatológiai kutatások (Zsidó és mtsai, 2020). A klinikai pszichológia szakterületén rendszeresen jelennek meg áttekintô kézikönyvek (pl. Kapitány-Föveny, Koncz és Varga, 2019).

Alig több mint 30 éve Ranschburg egy új tudományág születéseként mutatta be a fejlôdési pszichopatológiát, melynek célja a különbözô tudományterületek közötti integráció, valamint az „akadémikus” fejlődéslélektan és a „gyakorlati” klinikai pszichológia és pszichiátria közötti kapcsolat kialakítása (Ranschburg, 1989). Ennek a modern diagnosztikai gondolkodásnak és szemléletnek a bemutatását célozta meg egy MPSZ különszám, hazai kutatásokkal együtt, hazai múhelyek bemutatásával (Péley, 2013a). Ezzel a szemlélettel összefüggésben az utóbbi idôben a meghatározó trendek két nagy terület köré csoportosíthatók, a trauma és annak fejlôdési elôzményei, valamint a korai kapcsolati minôség. A fejlődéslélektani kutatások reneszánsza (Király, 2021), valamint a személyiségzavarok mentén felvetôdô új kérdések jelentôsen hozzájárultak klinikai szempontú kutatásokhoz. A veleszületett és környezeti kockázati tényezôk mellett hangsúlyossá váltak a protektív tényezók és az adaptáció is (Gervai és mtsai, 2007; Kéri, 2013; Hámori, 2013; Kállai és mtsai, 2021). A kötôdéselmélet megtermékenyítô keretnek mutatkozott a korai kapcsolatokban gyökerezô tipikus és atipikus fejlódés megértésében (Láng és Nagy, 2013). A tudatelmélet és annak klinikai kiterjesztése „régi jelenségeknek” ad új értelmet. Az anyai érzelemtükrözés, amely régi meghatározó fogalom a klinikai gyakorlat számára, új értelmezési keretben jelenik meg, és rámutat az atipikus kötôdési mintázat alakulásának folyamatára (Gergely és Watson, 1998; Koós és Gergely, 2001). A tudatelméleti deficit sajátosságait tárja fel Gyôri Miklós az autizmus spektrum területén (Gyốri, 2006). Az érzelemszabályozás és annak zavarai széles területet fednek le a kutatásokban, mivel minden pszichopatológiai jelenség érintett ebben (Bóna, Kun, Kökönyei és Demetrovics, 2013; Zsido és mtsai, 2021). A kutatások mentén a kapcsolati diagnosztika és a korai intervenció egyre hangsúlyosabbá válik, és szélesíti az alkalmazott kutatásokat (Danis, Scheuring, Gervai, Oates és Czinner, 2012; Hámori, 2021), valamint a longitudinális vizsgálatokat (Veroszta, Kopcsó, Boros, Kapitány és Spéder, 2020). A kognitív folyamatok közül a közös figyelem és az emlékezeti szervezôdés fejlődési sajátosságainak szintén van pszichopatológiai jelentôsége (Halász és Király, 2013; Varro-Horvath, Dorn és Labadi, 2017).

A pszichopatológiai jelenségek fejlôdésszempontú megközelítésében a korai idôszak mellett a serdülókor a másik kiemelt terület, ahol az újraszervezôdés során, az identitásalakulás folyamatában mutatkoznak meg a korai hiányok és elakadások, az identitásállapot összefüggései a mentális zavarokkal és személyiségzavarokkal (Reinhardt és mtsai, 2020; Rivnyak, Poharnok, Peley és Lang, 2021; Gyori és mtsai, 2021).

Mivel a belsố világ szervezôdésének a középpontjában a jelentés áll, illetve a megértés nem választható el a jelentéstôl, így a megfigyelések, kísérletek, kérdôívek mellett a szövegszintû elemzések is érintik a klinikai pszichológiát. Jelentôsek azok a közelmúlt- 
ban megjelent munkák, amelyek elsôsorban a kvalitatív szemlélet létjogosultságát mutatják be (Rácz, Kassai és Kaló, 2018). A narratívum tulajdonságaira építô megközelítések az élettörténeti epizódok elemzésével járulnak hozzá mind a diagnosztikához, mind a terápiás folyamat hatékonyságának növeléséhez, és jelentôs összefüggésekre mutatnak rá (Unoka, Berán és Pléh, 2012; Péley, 2013b). Az esettanulmány és az adatgyújtés ellentmondásaira és ennek mentén a klinikai munka nehézségeire mutat rá Csabai Márta (2017).

Ugyan kezdetben elsósorban a gyakorlat határozta meg a klinikai pszichológiát - és ez fontos identitásképzô elem volt -, mára számos és nemzetközileg is jelentôs empirikus munka és közlemény tartozik ehhez a területhez.

\section{IRODALOM}

Ajkay, K., Bagdy, E., Dobos, E., Erdélyi, I., Falus, F., Kapusi, Gy., \& Pajor, A. (2020). A 110 éve született Mérei Ferencre, a klinikai pszichológus szakma alapító tanítómesterére emlékezünk. Magyar Pszichológiai Szemle, 75(1), 5-12.

Bagdy, E., Pressing, L., Bugán, A., \& Zétényi, T. (1986). Az MMPI-próba: Elmélet és alkalmazás. Budapest: Akadémiai Kiadó.

Bóna, A., Kun, B., Kökönyei, Gy., \& Demetrovics, Zs. (2013). Az affektív szabályozás zavarai és következményei. Evészavarok és addiktív betegségek. Magyar Pszichológiai Szemle, 68(1), $71-88$.

Csabai, M. (2017). Eset-történet: a klinikai mesétôl az esetbankig. Budapest: Oriold és Társa.

Császár-Nagy, N. (2020). Quo vadis Rorschach-teszt? A Rorschach-próba múltja, jelene, krízisei, megújulása és jövôje. Magyar Pszichológiai Szemle, 75(1), 13-32.

Csigó, K. (2018). A Rorschach-teszt klinikai alkalmazása. Budapest: Medicina.

Csigó, K., Harsányi, A., Demeter, Gy., Rajkai, Cs., Németh, A., \& Racsmány, M. (2010). Long-term follow-up of patients with obsessive-compulsive disorder treated by anterior capsulotomy: A neuropsychological study. Journal of Affective Disorders, 126(1-2), 198-205.

Danis, I., Scheuring, N., Gervai, J., Oates, J., \& Czinner, A. (2012). A rövidített Szülő-Csecsemő Kapcsolat Skála magyar változatának (H-MORS-SF) pszichometriai mutatói nagy mintán. Psychiatria Hungarica, 27(6), 392-405.

Fekete, K., Török, E., Makkos, Z., Kelemen, O., Csigó, K., \& Kéri, S. (2020). Mentalization across the psychosis spectrum. Schizophrenia Research, 215, 471-472.

Gergely, Gy., \& Watson, J. S. (1998). A szülói érzelmi tükrözés szociális biofeedback modellje. A csecsemó érzelmi öntudatra ébredése és az önkontroll kialakulása. Thalassa, 9(1), $56-105$.

Gerô, Zs. (2017). Klinikai gyermekpszichológiai tanulmányok és más írások - elmélet és terápia kölcsönhatásai. Budapest: Flaccus Kiadó.

Gervai, J., Novak, A., Lakatos, K., Toth, I., Danis I., Ronai, Z., et al. (2007). Infant genotype may moderate sensitivity to maternal affective communications: attachment disorganization, quality of care, and the DRD4 polymorphism. Social Neuroscience, 2, 307-319.

Gyôri, M. (2006). Autism and cognitive architecture. Domain specificity and cognitive theorizing on autism. Budapest: Akadémiai Kiadó.

Gyori, D., Farkas, B. F., Horvath, L. O., Komaromy, D., Meszaros, G., Szentivanyi, D., \& Balazs, J. (2021). The Association of Nonsuicidal Self-Injury with Quality of Life and Mental Disorders in Clinical Adolescents-A Network Approach. International Journal of Environmental Research and Public Health, 18, 1840. DOI: https://doi.org/10.3390/ijerph18041840 
Halász, E., \& Király, I. (2013). Téves emlékek gyerekkorban - Trauma és befolyásolhatóság. Magyar Pszichológiai Szemle, 68(1), 57-70.

Harsányi, A., Csigó, K., \& Demeter, Gy. (2015). Kényszerbetegség - elmélet, kutatás, terápia. Budapest: Oriold.

Harsányi, A., Csigó, K., Rajkai, C., Demeter, G., Németh, A., \& Racsmány, M. (2014). Two types of impairments in OCD: Obsessions, as problems of thought suppression; compulsions, as behavioral- executive impairment. Psychiatry Research, 215(3), 651-658.

Hámori, E. (2013) Rizikófaktorok, adaptáció és reziliencia a korai fejlôdésben - A koraszülöttség a fejlódési pszichopatológia modelljében. Magyar Pszichológiai Szemle, 68(1), 7-22.

Hámori, E. (Ed.) (2021). A kapcsolati szemléletú pszichodiagnosztika a kora gyermekkori pszichés problémák felismerésében és az intervenció tervezésében. Budapest: Családbarát Ország Nonprofit Közhasznú Kft.

Horváth, Zs., Urbán, R., Kökönyei, Gy., \& Demetrovics, Zs. (2021). Kérdôives módszerek a klinikai és egészségpszichológia kutatásában és gyakorlatában. Budapest: Medicina.

Kállai, J., \& Kézdi, B. (2003). Új távlatok a klinikai pszichológiában. Budapest: Új Mandátum Kiadó.

Kállai, J., Vincze, G., Török, I. A., Hargitai, R., Rózsa, S., Hartung, I., et al. (2021). Cognitive Gain or Handicap: Magical Ideation and Self-Absorption in Clinical and Non-clinical Participants. Frontiers in Psychology, 12, 613074.

Kapitány-Föveny, M., Koncz, Zs., \& Varga, S. K. (Ed.) (2019). Klinikai szakpszichológia a gyakorlatban. Budapest: Medicina Kiadó.

Kéri, S. (2013) Lágy lélektani és szociológiai tényezôk egy kemény pszichiátriai betegség hátterében: a szkizofrénia relytéje. Magyar Pszichológiai Szemle, 68(1) 127-140.

Kéri, S., Kállai, I., \& Csigó, K. (2020). Enhanced Verbal Statistical Learning in Glossolalia. Cognitive Science, 44(7).

Király, I. (2021). A fejlôdéspszichológia Magyarországon az elmúlt 30 évben. Magyar Pszichológiai Szemle, 76(1), 229-235.

Kocsis-Bogár, K., Mészáros, V., \& Perczel-Forintos, D. (2018). Gender differences in the relationship of childhood trauma and the course of illness in schizophrenia. Comprehensive Psychiatry, 82, 84-88.

Koós, O., \& Gergely, Gy. (2001). A contingency-based approach to the etiology of „disorganized” attachment in infancy. The "flickering switch” hypothesis. Bulletin of the Menninger Clinic, 65(3), 397-410.

Láng, A., \& Nagy, L. (2013). Kötôdéselmélet és fejlôdési pszichopatológia - szemlélet, modellek, közvetítố mechanizmusok. Magyar Pszichológiai Szemle, 68(1), 23-37.

Maróthi, R., Csigó, K., \& Kéri, S. (2019). Early-Stage Vision and Perceptual Imagery in Autism Spectrum Conditions. Frontiers in Human Neuroscience, 13, 337. https://doi.org/10.3389/ fnhum.2019.00337

Mérei, F. \& Szakács, F. szerk. (1988a) Pszichodiagnosztikai vademecum I/1. Tankönyvkiadó

Mérei, F. \& Szakács, F. szerk. (1988b) Pszichodiagnosztikai vademecum I/2. Tankönyvkiadó.

Mérei, F. \& Szakács, F. szerk. (1994) Pszichodiagnosztikai vademecum II.

Mérei, F. (2002). A Rorschach-próba. Budapest: Medicina Könyvkiadó.

Miklosi, M., Szabo, M., Martos, T., Galambosi, E., \& Perczel Forintos, D. (2013). Cognitive Emotion Regulation Strategies Moderate the Effect of Parenting Self-Efficacy Beliefs on Parents' Anxiety Following Their Child's Surgery. Journal of Pediatric Psychology, 38(4), 462-471.

Nagy, J., \& Nagybányai, O. (2020). Tesztbizottság. Letöltve: 2021. 11. 01-én: http://mpt.hu/a-tarsasagrol/szervezet/bizottsagok/tesztbizottsag/

Nagy, Zs., \& Császár-Nagy, N. (2020). Az R-PAS (Rorschach Teljesítményértékelô Rendszer) bemutatása. Magyar Pszichológiai Szemle, 75(1), 67-72. 
Nemes, L. (2000). A bennünk élô gyermek. Budapest: Filum Kiadó.

Perczel Forintos, D., Rózsa, S., Pilling, J., \& Kopp, M. (2013). Proposal for a Short Version of the Beck Hopelessness Scale Based on a National Representative Survey in Hungary. Community Mental Health Journal, 49(6), 822-830.

Perczel-Forintos, D., Ajtay, Gy., Barna, Cs., Kiss, Zs., \& Komlósi, S. (Eds) (2018). Kérdốivek, becslốskálák a klinikai pszichológiában. Budapest: Semmelweis Kiadó.

Péley, B. (2013a). Pszichopatológia és fejlôdés. Diagnózis és terápia fejlôdési pszichopatológiai nézôpontból. Elôszó. Magyar Pszichológiai Szemle, 68(1), 3-6.

Péley, B. (2013b). Élettörténet - fejlődés és patológia. A narratív szemlélet és módszer haszna a diagnosztikában és a terápiában. Magyar Pszichológiai Szemle, 68(1), 141-157.

Rácz, J., Kassai, Sz., \& Kaló, Zs. (2018). A kvalitatív pszichológia új szenzibilitása. Elôszó. Magyar Pszichológiai Szemle, 73(1), 1-9.

Ranschburg, J. (1989) Egy új tudományág (a fejlôdési pszichopatológia) születésérôl. Pszichológia, 9(3) 331-340.

Reinhardt, M., Horváth, Zs., Urbán, R., Rice, K. G., Drubina, B., \& Kökönyei, Gy. (2020). Dissociative Tendencies Aggregate the Impact of Negative Life Events on Non-Suicidal Self-Injury among Male Juvenile Delinquents. Archives of Suicide Research, 30, 1-19.

Rivnyak, A., Poharnok, M., Peley, B., \& Lang, A. (2021). Identity Diffusion as the Organizing Principle of Borderline Personality Traits in Adolescents-A Non-clinical Study. Frontiers in Psychiatry, 12, 683288.

Rózsa, S., Kállai, J., Osváth, A., \& Bánki, M. Cs. (2005). Temperamentum és karakter: Cloninger pszichobiológiai modellje: a Cloninger-féle temperamentum és karakter kérdốv felhasználói kézikönyve. Budapest: Medicina.

Szabó, M., Mészáros, V., Sallay, J., Ajtay, G., Boross, V., Udvardy-Mészáros, Á., et al. (2016). The Beck Hopelessness Scale: Specific Factors of Method Effects? European Journal of Psychological Assessment, 32(2), 111-118.

Szakács, F. (2010). November 100 (Szubjektív emlékezés Mérei Ferencre). Magyar Pszichológiai Szemle, 65(2), 343-350.

Unoka, Zs., Berán, E., \& Pléh, Cs. (2012). Narrative constructions and the life history issue in brain-emotions relations. Behavioral and Brain Sciences, 35(1), 168-169.

Varro-Horvath, D. A., Dorn, K., \& Labadi, B. (2017). Understanding deceptive intentions behind pointing gestures in 12-15-month-old infants. Infant Behavior \& Development, 44, 121-124.

Veroszta, Zs., Kopcsó, K., Boros, J., Kapitány, B., \& Spéder, Zs. (2020). Tracking the development of children from foetal age: an introduction to Cohort '18 Growing Up in Hungary. Longitudinal and Life Course Studies, 11(4), 587-598.

Zsidó, A., Arató N., Láng, A., Lábadi, B., Stecina, D., \& Bandi, Sz. (2020). The connection and background mechanism of social fears and problematic social networking site use: a Structural Equation Modeling analysis. Psychiatry Research, 292, 113323.

Zsido, A. N., Arato, N., Lang, A., Labadi, B., Stecina, D., \& Bandi, Sz. A. (2021). The role of maladaptive cognitive emotion regulation strategies and social anxiety in problematic smartphone and social media use. Personality and Individual Differences, 173, 110647. 


\section{CLINICAL PSYCHOLOGY IN HUNGARY FOR THE LAST 30 YEARS}

\section{PÉLEY, BERNADETTE}

The foundations of clinical psychology started from professional practice, with the systematization and adaptation of diagnostic methods. Over the last thirty years, research has been carried out in various fields, and clinical psychology has differentiated. Developmental psychopathology represents a new perspective in clinical psychological thinking. This new framework induces recent researches in multiple psychopathological phenomena.

Keywords: methods, practice and research, developmental psychopathology

A cikk a Creative Commons Attribution 4.0 International License (https://creativecommons. org/licenses/by/4.0/) feltételei szerint publikált Open Access közlemény, melynek szellemében a cikk bármilyen médiumban szabadon felhasználható, megosztható és újraközölhetô, feltéve, hogy az eredeti szerzô és a közlés helye, illetve a CC License linkje és az esetlegesen végrehajtott módosítások feltüntetésre kerülnek. (SID_1) 